\title{
Antioxidant Effects of Walnut Leaves and Sweet Cherry Stems on Color, Lipid Oxidation and Sensory Quality of Cooked Pork Patties
}

\author{
Andrei Iulian BORUZI ${ }^{1}$, Violeta NOUR ${ }^{1,2 *}$ \\ ${ }^{1}$ Dunărea de Jos' University of Galați, Faculty of Food Science and Engineering, 111 Domnească Street, 800201 Galați, \\ Romania; boruzi@gmail.com \\ ${ }^{2}$ University of Craiova, Department of Horticulture and Food Science, 13 A.I. Cuza Street, 200585 Craiova, \\ Romania; vionor@yahoo.com (*orrespondingauthor)
}

\begin{abstract}
The effects of walnut leaf powder (WLP), walnut leaf extract (WLE) and cherry stem extract (CSE) on the oxidative and color stability of cooked pork patties were determined and compared with $0.01 \%$ butylated hydroxytoluene (BHT) and control (without antioxidant). Instrumental color, $\mathrm{pH}$, total phenolic content, antioxidant activity, thiobarbituric acid reactive substances (TBARS) and sensory attributes were determined on manufactured patties initially (time 0 ) and after 5, 10 and 15 days of refrigerated storage. Addition of walnut leaf extract to pork patties was more effective than cherry stem extract in controlling lipid oxidation and color changes during cold storage, in agreement with results from the in vitro antioxidant activity. The natural additives significantly $(\mathrm{p}<0.05)$ increased phenolic content and antioxidant activity in cooked pork patties as compared to control and BHT treated samples, throughout the storage period. After 15 days, the TBARS values were significantly $(\mathrm{p}<0.05)$ reduced from 3.01 in control patties to $2.43,1.58,1.83$ and 1.19 mg malondialdehyde per $\mathrm{kg}$ samples in patties with BHT, WLE, CSE and WLP, respectively. Addition of extracts showed positive effects on sensory attributes, the highest scores being achieved by WLP treated samples.
\end{abstract}

Keywords: antioxidant activity; cherry stems; discoloration; lipid oxidation; meat products; walnut leaves

\section{Introduction}

The oxidation of lipids and proteins is the main, nonmicrobial cause of meat quality deterioration during processing and storage (Falowo et al., 2014). Oxygen free radicals formed from molecular oxygen, particularly the reactive oxygen species (ROS) and reactive nitrogen species (RNS), interact with proteins, fatty acids and nucleic acids, acting as intermediate agents in essential oxidation-reduction reactions (Moylan et al., 2014). Oxidation of meat reduces its sensory quality due to discoloration through the oxidation of myoglobin and to the formation of volatile aromatic compounds which impart rancid odour and off-flavors (Palmieri and Sblendorio, 2007). In addition, oxidative processes determine formation of toxic compounds, reduction of shelf life and nutrient and drip losses (Contini et al., 2014). The high susceptibility to oxidative deterioration of meat is due to the high concentrations of unsaturated lipids, heme pigments and oxidizing agents in the muscle tissue and to the rapid depletion of endogenous antioxidants after slaughter (Xiao et al., 2013). The relatively high proportion of unsaturated fatty acids of pork makes it even more susceptible to lipid peroxidation (Mc Carthy et al., 2001).
In addition, meat grinding promotes lipid oxidation due to the increased exposure to air of meat lipids (Rojas and Brewer, 2008).

Vacuum or modified atmosphere packaging can be used to prevent or reduce lipid oxidation. Also, in order to delay lipid oxidation in meat products, synthetic antioxidants, such as butylated hydroxyl anisole (BHA), butylated hydroxyl toluene (BHT), propyl gallate and tertiary butyl hydroxyl quenone (TBHQ), have been applied extensively. However, the concerns about the toxic and carcinogenic effects of synthetic antioxidants together with the consumer preferences for natural ingredients have stimulated interest for exploring effective antioxidants from natural sources, especially of plant origin (Naveena et al., 2008; Karre et al., 2013).

Several authors have reported the efficacy of culinary herbs and spices (Biswas et al., 2011; Sampaio et al., 2012), vegetables (Smet et al., 2008; Banerjee et al., 2012), fruits (Carpenter et al., 2007; Jia et al., 2012) as well as residual vegetal sources (Ahn et al., 2007; Kanatt et al., 2010; Rodriguez-Carpena et al., 2011) for reducing lipid and protein oxidation in some types of meat.

In recent years, special attention has been paid to a number of medicinal plants that could be used as potential sources of antioxidants. Leaf extracts of green tea (Rababah 
764

et al., 2006), Ginkgo biloba (Kobus-Cisowska et al., 2014), Hypericum perforatum L. (Sanchez-Muniz et al., 2012), butterbur (Kim et al., 2013), olive (Hayes et al., 2011), Moringa oleiferia (Das et al., 2012) have been shown to display remarkable antioxidant potential and inhibitory effects on the oxidative degradation processes in meat systems. Phenolic compounds are the major constituents of these plant materials that contribute to their antioxidant capacity due to their ability to scavenge free radicals, donate hydrogen atoms and chelate metal cations (Balasundram $e t$ al., 2006).

Walnut (Juglans regia L.) leaves are abundant in phenolic compounds including phenolic acids, naphtoquinones and flavonoids as secondary metabolites. They are frequently used to prepare infusions as they have been widely used in traditional medicine for treatment of skin inflammations, hyperhidrosis and ulcers and for their antidiarrheic, antihelmintic, antiseptic and astringent properties (Amaral et al., 2004; Pereira et al., 2007). There are many studies regarding the pharmaceutical effects of walnut leaves (Kaumar et al., 2003) proving their antimicrobial, antimutagenic and antiproliferative activities (Pereira et al., 2007; Salimi et al., 2012).

The infusions and decoctions prepared from sweet cherry (Prunus avium L.) stems are traditionally used as sedatives, diuretics and draining (Hooman et al., 2009), especially helping to promote proper kidney function. The anti-inflammatory and diuretic properties are related with their high content of natural antioxidants, i.e. phenolic compounds (Ademović et al., 2017), the stems being a good candidate for nutraceutical or pharmaceutical products (Bastos et al., 2015).

Walnut leaves and sweet cherry stems have been well investigated for their antioxidant activity but their use as a natural antioxidant in meat products to control lipid peroxidation has not been studied. The objective of the present work was to evaluate the effectiveness of walnut leaf powder and of extracts from walnut leaves and cherry stems as inhibitors of lipid oxidation and color deterioration in cooked pork patties subjected to refrigerated storage.

\section{Materials and Methods}

Vegetable material: preparation of powders and extracts

Fresh walnut (Juglans regia L.) leaves and sweet cherry (Prunus avium L.) stems were collected randomly in the middle of June 2016 from trees growing in the experimental orchard of the University of Craiova located at Râmnicu Vâlcea (Romania) research station $\left(45^{\circ} 07^{\prime} \mathrm{N} / 24^{\circ} 22^{\prime} \mathrm{E}\right)$. The samples were properly cleaned and dried in shade. The dried walnut leaves and cherry stems were reduced to a fine powder (20 mesh), mixed to obtain homogenous samples and stored in the dark at room temperature in high density polyethylene bags for further use. For preparation of the extracts, $20 \mathrm{~g}$ of dried leaf or stem powder were mixed with $100 \mathrm{ml}$ boiling distilled water and left for $1 \mathrm{~h}$. The extracts obtained by filtration were used in further experiments.

Preparation of pork patties

Fresh pork meat and back fat were purchased from a local meat processing plant. All separable fat and visible connective tissues were removed from meat. Lean pork meat and pork back fat were ground through a $3 \mathrm{~mm}$ plate and mixed to have $20 \%$ fat level. The mixture was divided to provide five experimental variants: I) $\mathrm{C} 0$ - Control (meat + $1.5 \%$ salt $+5.5 \%$ water); II) C1 - Control with BHT (meat $+1.5 \% \mathrm{w} / \mathrm{w}$ salt $+5.5 \%$ water $+0.1 \%$ BHT); III) WLE $(\mathrm{meat}+1.5 \% \mathrm{w} / \mathrm{w}$ salt $+5.5 \%$ walnut leaf extract $) ; \mathrm{IV})$ CSE $($ meat $+1.5 \% \mathrm{w} / \mathrm{w}$ salt $+5.5 \%$ cherry stem extract) V) WLP $($ meat $+1.5 \%$ w $/ \mathrm{w}$ salt $+5.5 \%$ water $+0.5 \%$ walnut leaf powder). Solid additives were dissolved in water or extract prior to mixing with the meat batter. Immediately after adding all ingredients, meat samples were thoroughly mixed and made into patties manually (50 g each). The samples were placed in an electric oven preheated for 15 minutes at $180^{\circ} \mathrm{C}$ and allowed to cook for 10 minutes until $75 \pm 1{ }^{\circ} \mathrm{C}$ in the meat center. After cooling to room temperature, the patties were aerobically packed in polyethylene bags. They were analysed for sensory attributes, instrumental color, total phenolic content, $\mathrm{pH}, \mathrm{ABTS}$ antioxidant activity, and thiobarbituric acid reactive substances (TBARS) value as described below at $0,5,10$ and 15 days of storage at $4{ }^{\circ} \mathrm{C}$ in darkness.

\section{Proximate composition and cooking yield}

Moisture content was determined by weight loss after 12 $h$ at $105^{\circ} \mathrm{C}$ in a drying oven according SR ISO 1442/2010, fat content by Soxhlet method (SR ISO 1444/2008) and protein content by Kjeldahl method (SR ISO 937/2007) with an automatic Kjeldahl nitrogen analyzer (UDK 149 Velp Scientific, Italy). Cooking yield was calculated by dividing cooked product weight by the raw uncooked weight and expressed as per cent.

\section{pH}

$\mathrm{pH}$ values of the cooked patties were measured using a multiparameter instrument Hanna HI255 after blending $10 \mathrm{~g}$ of sample with $50 \mathrm{ml}$ of distilled water for $60 \mathrm{~s}$ in a homogenizer (Braun MQ5137BK, 750W).

\section{Totalphenolic content}

Total phenolics were estimated colorimetrically by Folin-Ciocalteu assay as proposed by Singleton et al. (1999). Aliquots of extracts $(0.1 \mathrm{~mL})$ were mixed with $5 \mathrm{~mL}$ of distilled water and $0.5 \mathrm{~mL}$ of Folin-Ciocalteu reagent. After $30 \mathrm{sec}$ to $8 \mathrm{~min}$ of reaction, $1.5 \mathrm{~mL}$ of $\mathrm{Na}_{2} \mathrm{CO}_{3}(20 \%)$ and $2.9 \mathrm{~mL}$ of distilled water were added. The absorbance was measured at $765 \mathrm{~nm}$ in a Varian Cary $50 \mathrm{UV}$ spectrophotometer (Varian Co., USA) after 30 minutes of incubation at $40^{\circ} \mathrm{C}$. Results were expressed as milligrams of gallic acid equivalents per $100 \mathrm{~g}$.

\section{Total flavonoid content}

Total flavonoids were measured by the aluminum chloride colorimetric method developed by Zhishen et al. (1999). An aliquot (1 mL) of appropriately diluted sample or standard solutions of quercetin $(20-100 \mathrm{mg} / \mathrm{L})$ was added to a $10 \mathrm{~mL}$ volumetric flask containing $4 \mathrm{~mL} \mathrm{H}_{2} \mathrm{O}$. At zero time, $0.3 \mathrm{~mL} 5 \% \mathrm{NaNO}_{2}$ was added to the flask. After $5 \mathrm{~min}, 0.3 \mathrm{~mL} 10 \% \mathrm{AlCl}_{3}$ was added. Finally, at $6 \mathrm{~min}$, $2 \mathrm{~mL} 1 \mathrm{M} \mathrm{NaOH}$ was added to the mixture and the volume 
was made up to $10 \mathrm{~mL}$ with $\mathrm{H}_{2} \mathrm{O}$. Absorbance of the mixture was determined at $510 \mathrm{~nm}$ against reagent blank prepared with water. Total flavonoid content of leaf extract was expressed as $\mathrm{mg}$ quercetin $(\mathrm{QE})$ per $100 \mathrm{~g}$.

\section{ABTS free radical scavenging activity}

Antioxidant activity of the samples was measured using an ABTS (2,29-azinobis-3-ethylbenzothiazoline-6-sulfonic acid) procedure (Re et al., 1999). The ABTS cation radical solution (ABTS+) was prepared through the reaction of 7.0 $\mathrm{mM}$ ABTS solution $(5 \mathrm{ml})$ and $145 \mathrm{mM}$ potassium persulfate solution $(88 \mu \mathrm{L})$, after incubation at room temperature, in the dark for $16 \mathrm{~h}$. The ABTS+ solution was then diluted with $80 \%$ ethanol to obtain an absorbance of $0.700 \pm 0.005$ at $734 \mathrm{~nm}$. Twelve milliliters of ABTS+ solution $(0.700 \pm 0.005$ absorbance) were added to $120 \mu \mathrm{l}$ of sample extract and vigorously mixed in a vortex homogenizer. After 6 minutes, the absorbance at $734 \mathrm{~nm}$ was recorded using ethyl alcohol as blank. Ethanolic solutions of known Trolox concentrations (100-2000 $\mu \mathrm{M}$ Trolox/l) were used for calibration and the results were expressed as $\mathrm{mM}$ Trolox $/ 100 \mathrm{~g}$.

\section{Color measurement}

Color was measured on the surface of the cooked pork patties from four randomly chosen spots with a reflectance colorimeter (PCE-CSM 1, PCE Instruments, UK) standardized with a white reference ceramic tile. Color was expressed as $\mathrm{L}^{*}$ (lightness), $\mathrm{a}^{*}$ (redness), and $\mathrm{b}^{*}$ (yellowness) reflectance values. Hue angle was calculated as $\tan ^{-1}\left(\mathrm{~b}^{*} / \mathrm{a}^{*}\right)$ and chroma as $\left(\mathrm{a}^{* 2}+\mathrm{b}^{* 2}\right)^{1 / 2}$.

\section{Thiobarbituric acid reactive substances}

TBARS values ( $\mathrm{mg}$ malondialdehyde $/ \mathrm{kg}$ ) were determined spectrophotometrically according to the procedure described by Witte et al. (1970) with slight modifications. For extraction, five grams of meat sample were homogenised in a vortex mixer with $12.5 \mathrm{~mL}$ of $20 \%$ trichloroacetic acid then transferred to a $25-\mathrm{mL}$ volumetric flask and dilluted up to the volume with cold distilled water. After filtration with qualitative filter paper $(12.5 \mathrm{~mm}), 5 \mathrm{ml}$ of filtrate were mixed with $5 \mathrm{ml}$ of an aqueous solution of $0.02 \mathrm{M}$ 2-thiobarbituric acid (TBA) in capped test tubes. The samples were incubated in a water bath at $100^{\circ} \mathrm{C}$ for $35 \mathrm{~min}$ and then cooled in cold water. The absorbance was measured at $532 \mathrm{~nm}$ with a Varian Cary 50 UV spectrophotometer (Varian Co., USA) against a blank containing $5 \mathrm{~mL}$ of the same trichloroacetic acid solution and $5 \mathrm{~mL}$ of TBA solution. The results were calculated from the standard curve of 1,1,3,3-tetraethoxypropane (Sigma-Aldrich) and expressed as $\mathrm{mg}$ of malondialdehyde (MDA) per kg of meat.

\section{Sensory evaluation}

Sensory evaluation of stored patties was performed on day $0,5,10$ and 15 of storage by ten panelists who were graduate students and staff members in the Department of Food Science, University of Craiova. They rated each sample for appearance, color, flavor and general acceptability on a 10-point hedonic scale (1=extremely undesirable, $10=$ extremely desirable). Patties were warmed in a microwave oven for $20 \mathrm{~s}$ just before sensory evaluation and coded samples were served at room temperature. Water was served for cleansing the mouth between samples.

\section{Statistical analysis}

All experiments were done in triplicate and results are reported as mean \pm standard deviation. The analysis of variance (ANOVA) was used to assess the effects of treatments and storage time. Means were compared by the Duncan's multiple range test and statistical significance was identified at $p<0.05$. Statgraphics Centurion XVI software (StatPoint Technologies, VA, USA) was employed in this study.

\section{Results and Discussion}

Total phenolics, total flavonoids and antioxidant activity

Walnut leaf powder and extracts obtained from walnut leaves and cherry stems were tested for total phenolic content, total flavonoid content and ABTS antioxidant activity (Table 1). In the walnut leaf extract, both total flavonoid content and antioxidant activity were higher than in the cherry stem extract. Walnut leaf was previously reported to be a rich source of flavonoids (Martinez et al., 2009; Carvalho et al., 2010). Total phenolic content, however, was higher in cherry stem extracts than in walnut leaf extracts.

\section{Proximate composition and cooking yield}

The proximate composition of the cooked pork patties from various treatments is presented in Table 2. Moisture contents increased significantly $(p<0.05)$ only on addition of WLP indicating that the powder resulted in retention of moisture. These results are in good agreement with those on cooking yield that was significantly higher in samples with addition of WLP. The fat and protein contents of the control samples $(\mathrm{C} O$ and $\mathrm{C} 1$ ) were the highest among all treatments $(\mathrm{p}<0.05)$, probably as a result of the higher moisture loss during cooking of these samples.

\section{Instrumental color}

The evolution of lightness $\left(\mathrm{L}^{*}\right)$, redness $\left(\mathrm{a}^{*}\right)$, yellowness $\left(b^{*}\right)$, hue $(h)$ and chroma $(C)$ values during 15 days of storage is presented in Table 3 .

Table 1. Total phenolic content, total flavonoid content and antioxidant activity in walnut leaf and cherry stem extracts and in walnut leaf powder*

\begin{tabular}{cccc}
\hline Sample & $\begin{array}{c}\text { Total phenolic content } \\
(\mathrm{mg} \mathrm{GAE} / 100 \mathrm{~g} \mathrm{DW})\end{array}$ & $\begin{array}{c}\text { Total flavonoids } \\
(\mathrm{mg} \mathrm{QE} / 100 \mathrm{~g} \mathrm{DW})\end{array}$ & $\begin{array}{c}\text { ABTS antioxidant activity } \\
(\mathrm{mmol} \text { Trolox/100 g DW })\end{array}$ \\
\hline Walnut leaf powder & $2898.28 \pm 128.56$ & $1956.76 \pm 87.55$ & $16.28 \pm 0.87$ \\
Walnut leaf extract & $497.67 \pm 23.34$ & $353.66 \pm 16.45$ & $3.67 \pm 0.21$ \\
Cherry stem extract & $685.66 \pm 31.15$ & $145.35 \pm 11.19$ & $2.84 \pm 0.14$ \\
\hline${ }^{*}$ Values are expressed as mean \pm standard deviation.
\end{tabular}


Table 2. Cooking yield, moisture, protein and fat content of pork patties

\begin{tabular}{|c|c|c|c|c|}
\hline Treatment ${ }^{*}$ & Moisture $(\%)^{* *}$ & Protein (\%) & Fat $(\%)$ & Cooking yield (\%) \\
\hline $\mathrm{C} 0$ & $55.39 \pm 0.63^{\mathrm{a}}$ & $21.68 \pm 0.38^{c}$ & $18.62 \pm 0.26^{d}$ & $70.8 \pm 1.10^{a}$ \\
\hline $\mathrm{C} 1$ & $55.61 \pm 0.40^{a}$ & $21.43 \pm 0.4 b^{b c}$ & $18.39 \pm 0.23^{\mathrm{cd}}$ & $71.2 \pm 1.78^{\mathrm{ab}}$ \\
\hline WLE & $55.96 \pm 0.52^{\mathrm{ab}}$ & $20.86 \pm 0.29^{9 \mathrm{~b}}$ & $17.48 \pm 0.34^{\mathrm{ab}}$ & $72.8 \pm 1.10^{b}$ \\
\hline CSE & $55.82 \pm 0.29^{a}$ & $21.12 \pm 0.33^{\text {abc }}$ & $17.88 \pm 0.38^{\mathrm{bc}}$ & $71.2 \pm 1.10^{\mathrm{ab}}$ \\
\hline WLP & $56.71 \pm 0.44^{b}$ & $20.46 \pm 0.36^{a}$ & $17.14 \pm 0.28^{a}$ & $72.8 \pm 1.10^{\mathrm{b}}$ \\
\hline
\end{tabular}

(meat $+1.5 \% \mathrm{w} / \mathrm{w}$ salt $+5.5 \%$ water $+0.1 \% \mathrm{BHT}) \cdot \mathrm{WLF}($ meat $+1.5 \% \mathrm{w} / \mathrm{w}$ salt + $5.5 \%$ walnut leaf extract); CSE (meat $+1.5 \% \mathrm{w} / \mathrm{w}$ salt $+5.5 \%$ cherry stem extract); WLP (meat $+1.5 \% \mathrm{w} / \mathrm{w}$ salt $+5.5 \%$ water $+0.5 \% \mathrm{walnut}$ leaf powder)

${ }^{* *}$ Means with different superscript within a column are significantly different $(\mathrm{p}<0.05)$

Table 3. Color parameters of the pork patties samples during refrigerated storage for 15 days*

\begin{tabular}{|c|c|c|c|c|c|}
\hline \multirow{2}{*}{ Color parameters } & \multirow{2}{*}{ Treatment* } & \multicolumn{4}{|c|}{ Storage period (days) ${ }^{* *}$} \\
\hline & & 0 & 5 & 10 & 15 \\
\hline \multirow{5}{*}{$\mathrm{L}^{*}$} & $\mathrm{C} 0$ & $71.23 \pm 1.49^{\mathrm{bA}}$ & $79.53 \pm 2.82^{\mathrm{cB}}$ & $80.56 \pm 3.11^{\mathrm{cB}}$ & $78.24 \pm 1.32^{\mathrm{dB}}$ \\
\hline & $\mathrm{C} 1$ & $80.28 \pm 0.16^{\mathrm{dB}}$ & $78.10 \pm 1.27^{\mathrm{cA}}$ & $81.09 \pm 1.77^{\mathrm{cB}}$ & $77.58 \pm 1.63^{\mathrm{dA}}$ \\
\hline & WLE & $69.77 \pm 1.49^{\mathrm{cB}}$ & $74.53 \pm 1.30^{\mathrm{bB}}$ & $72.45 \pm 0.61^{\mathrm{bB}}$ & $70.06 \pm 1.84^{\mathrm{bA}}$ \\
\hline & CSE & $71.61 \pm 0.71^{\mathrm{bA}}$ & $73.70 \pm 1.05^{\mathrm{bB}}$ & $74.78 \pm 2.09^{\mathrm{bB}}$ & $73.18 \pm 2.22^{\mathrm{cB}}$ \\
\hline & WLP & $62.31 \pm 2.52^{\mathrm{aA}}$ & $65.00 \pm 2.24^{\mathrm{aAB}}$ & $66.57 \pm 0.86^{\mathrm{aB}}$ & $62.87 \pm 1.20^{\mathrm{aA}}$ \\
\hline \multirow{5}{*}{$a^{*}$} & $\mathrm{C} 0$ & $4.47 \pm 0.14^{\mathrm{aB}}$ & $4.82 \pm 0.34^{\mathrm{bB}}$ & $3.31 \pm 0.27^{\mathrm{aA}}$ & $3.15 \pm 0.06^{\mathrm{aA}}$ \\
\hline & $\mathrm{C} 1$ & $7.92 \pm 0.42^{\mathrm{dC}}$ & $6.24 \pm 0.46^{\mathrm{cB}}$ & $4.84 \pm 0.55^{\mathrm{bA}}$ & $4.57 \pm 0.26^{\mathrm{bA}}$ \\
\hline & WLE & $5.82 \pm 0.47^{\mathrm{bA}}$ & $6.05 \pm 0.33^{\mathrm{cB}}$ & $5.36 \pm 0.26^{\mathrm{cA}}$ & $5.08 \pm 0.31^{\mathrm{cA}}$ \\
\hline & CSE & $5.93 \pm 0.06^{\mathrm{cB}}$ & $5.87 \pm 0.30^{\mathrm{cB}}$ & $5.84 \pm 0.26^{\mathrm{cB}}$ & $5.10 \pm 0.20^{\mathrm{cA}}$ \\
\hline & WLP & $4.09 \pm 0.38^{\mathrm{aB}}$ & $3.68 \pm 0.84^{\mathrm{aB}}$ & $3.51 \pm 0.15^{\mathrm{aAB}}$ & $2.86 \pm 0.43^{\mathrm{aA}}$ \\
\hline \multirow{5}{*}{$b^{*}$} & $\mathrm{C} 0$ & $13.99 \pm 0.32^{\mathrm{abAB}}$ & $14.06 \pm 0.83^{\mathrm{aC}}$ & $13.83 \pm 0.32^{\mathrm{bA}}$ & $14.71 \pm 0.37^{7 \mathrm{BC}}$ \\
\hline & $\mathrm{C} 1$ & $15.58 \pm 0.43^{\mathrm{dB}}$ & $15.11 \pm 0.53^{\mathrm{aAB}}$ & $14.52 \pm 0.80^{\mathrm{cA}}$ & $14.67 \pm 0.70^{\mathrm{bAB}}$ \\
\hline & WLE & $15.35 \pm 1.02^{\mathrm{aA}}$ & $16.45 \pm 0.42^{\mathrm{bD}}$ & $14.62 \pm 0.44^{\mathrm{CB}}$ & $15.39 \pm 0.54^{\mathrm{bC}}$ \\
\hline & CSE & $13.00 \pm 0.51^{\mathrm{cdB}}$ & $13.92 \pm 0.50^{\mathrm{aA}}$ & $13.09 \pm 0.09^{\mathrm{aA}}$ & $13.13 \pm 0.63^{\text {aA }}$ \\
\hline & WLP & $14.53 \pm 0.97^{\mathrm{bcB}}$ & $14.43 \pm 1.55^{\mathrm{aB}}$ & $13.69 \pm 0.25^{\mathrm{abAB}}$ & $12.92 \pm 0.56^{\mathrm{aA}}$ \\
\hline \multirow{5}{*}{$\mathrm{C}$} & $\mathrm{C} 0$ & $14.69 \pm 0.29^{2 \mathrm{~A}}$ & $15.81 \pm 0.89^{9 \mathrm{~B}}$ & $14.22 \pm 0.38^{\mathrm{aA}}$ & $15.05 \pm 0.36^{\mathrm{AB}}$ \\
\hline & $\mathrm{C} 1$ & $17.48 \pm 0.26^{\mathrm{bB}}$ & $16.35 \pm 0.62^{\mathrm{abA}}$ & $15.31 \pm 0.90^{\mathrm{bA}}$ & $15.37 \pm 0.75^{\mathrm{bcA}}$ \\
\hline & WLE & $16.45 \pm 1.11^{\mathrm{aA}}$ & $17.53 \pm 0.50^{\mathrm{bC}}$ & $15.57 \pm 0.49^{\mathrm{bB}}$ & $16.21 \pm 0.49^{\mathrm{c} B}$ \\
\hline & CSE & $14.29 \pm 0.49^{\mathrm{aB}}$ & $15.11 \pm 0.58^{\mathrm{aA}}$ & $14.47 \pm 0.45^{\mathrm{aA}}$ & $14.08 \pm 0.65^{\mathrm{aA}}$ \\
\hline & WLP & $15.11 \pm 1.02^{\mathrm{aB}}$ & $14.90 \pm 1.70^{\mathrm{aB}}$ & $14.13 \pm 0.26^{\mathrm{aAB}}$ & $13.23 \pm 0.61^{\mathrm{aA}}$ \\
\hline \multirow{5}{*}{$\mathrm{h}$} & $\mathrm{C} 0$ & $72.27 \pm 0.81^{\mathrm{cA}}$ & $72.29 \pm 0.52^{\mathrm{cA}}$ & $76.55 \pm 0.81^{\mathrm{dB}}$ & $77.92 \pm 0.42^{c \mathrm{C}}$ \\
\hline & $\mathrm{C} 1$ & $63.04 \pm 1.76^{\mathrm{aA}}$ & $67.57 \pm 1.11^{\mathrm{aB}}$ & $71.61 \pm 1.35^{\mathrm{cC}}$ & $72.73 \pm 0.19^{\mathrm{bC}}$ \\
\hline & WLE & $68.94 \pm 0.30^{\mathrm{bA}}$ & $69.81 \pm 0.57^{\mathrm{bAB}}$ & $69.88 \pm 0.42^{\mathrm{bB}}$ & $71.70 \pm 1.37^{\mathrm{bC}}$ \\
\hline & CSE & $68.48 \pm 0.65^{\mathrm{bC}}$ & $67.15 \pm 0.32^{\mathrm{aB}}$ & $66.20 \pm 0.36^{\mathrm{aA}}$ & $68.17 \pm 0.46^{\mathrm{aC}}$ \\
\hline & WLP & $74.27 \pm 0.91^{\mathrm{dA}}$ & $75.83 \pm 1.85^{\mathrm{dAB}}$ & $75.63 \pm 0.54^{\mathrm{dAB}}$ & $77.52 \pm 1.56^{\mathrm{cB}}$ \\
\hline
\end{tabular}

${ }^{7}$ Legend: $\mathrm{C} 0$ - Control (meat $+1.5 \%$ salt $+5.5 \%$ water); $\mathrm{C} 1$ - Control with BHT (meat $+1.5 \% \mathrm{w} / \mathrm{w}$ salt $+5.5 \%$ water $\left.+0.1 \% \mathrm{BHT}\right) ; \mathrm{WLE}(\mathrm{meat}+1.5 \% \mathrm{w} / \mathrm{w}$ salt + $5.5 \%$ walnut leaf extract); CSE (meat $+1.5 \% \mathrm{w} / \mathrm{w}$ salt $+5.5 \%$ cherry stem extract); WLP (meat $+1.5 \% \mathrm{w} / \mathrm{w}$ salt $+5.5 \%$ water $+0.5 \%$ walnut leaf powder)

${ }^{* *}$ Different lowercase letters indicate significant difference at $\mathrm{p}<0.05$ level between different treatments, while different uppercase letters are indicative of the same within each treatment during the storage period.

The additives had a significant effect on the color displayed by freshly made cooked pork patties (day 0). BHT addition led to patties with significantly higher $\mathrm{L}^{*}$ values, CSE did not significantly affect lightness while WLP and WLE resulted in a darker color (lower $\mathrm{L}^{*}$ value).

Lightness decreases have been also reported in previous studies as a result of the addition of antioxidant plant powders and extracts to ground pork meat (Qin et al., 2013) and chicken meat patties (Naveena et al., 2008; Devatkal et al., 2011). In contrast, others studies reported that the lightness of the raw and cooked pork patties was not affected by the addition of avocado (RodriguezCarpena et al., 2011) or grape seed extracts (Carpenter $e$ t al., 2007). BHT and plant extracts led to patties with significantly higher $\mathrm{a}^{*}$ values while the samples with WLP had the lowest $\mathrm{a}^{*}$ values due to the deep green color of the walnut leaf. Higher $b^{*}$ values $(p<0.05)$ were found at pork patties with BHT, WLE or WLP as compared with the control. Similar findings were reported by Jo et al. (2003) for raw and cooked pork patties with added green tea leaf extract and powder.

Redness significantly $(\mathrm{p}<0.05)$ decreased during storage period in all treatments suggesting that pigment oxidation can still occur even if antioxidants are added. This trend of decreasing $\mathrm{a}^{*}$ values may be due to interference between lipid oxidation and colour deterioration in meats (Lynch and Faustman, 2000).

In salt containing treatments, the change in colour from red to brown could be attributed to the formation of metmyoglobin by the oxidation of myoglobin (Nerín et al., 
2006). Similar reductions in redness with increasing storage time have been reported in many studies (Mc Carthy et al., 2001; Qin et al., 2013).

Among treatments, samples with BHT had a more evident reduction in the $\mathrm{a}^{*}$ value over 15 days of refrigerated storage. Similar results were reported by Selani et al. (2011), who observed that BHT was less effective than phenolicrich extracts in preventing colour alterations in raw and cooked chicken meat during frozen storage. They explained this finding by arguing that BHT is a lipid soluble free radical scavenger that is enable to inactivate water-soluble free radicals as compared with polyphenols which are mostly water soluble compounds and thus could directly interact with myoglobin, a water-soluble protein, to exert their free radical scavenging action. Polyphenols from walnut leaf and cherry stem extracts have been proved to act as efficient radical scavengers in vitro (Amaral et al., 2004; Pereira et al., 2007; Ademović et al., 2017).

The progress of yellowness was different amongst treatments. Yellowness of samples treated with BHT and WLP showed a decreasing trend during the storage period while it increased after 5 days of storage and decreased afterwards at the samples with added extracts. A similar variation was reported by Devatkal et al. (2011) in raw chicken patties treated with pomegranate juice and rind extract. The yellowness of the control patties significantly increased during the storage period. A similar variation was observed in previous studies and it was attributed to the accumulation of Schiff pigments (lipofuschin) from lipid to protein complexes as a result of oxidative stress (Chelh et al., 2007). Hue values showed an increasing trend with storage period in all the treatments.

\section{$p H$}

Table 4 shows the $\mathrm{pH}$ values (mean \pm standard deviation) of the cooked pork patties packed under aerobic conditions. $\mathrm{pH}$ values varied from 5.79 to 6.29 during 15 storage days. At the beginning of the experiment (day 0 ), the $\mathrm{pH}$ values of samples treated with WLE and WLP were significantly $(p<0.05)$ lower than the control samples. This effect could be attributed to the high phenolic acid level of the walnut leaf extract and powder. Ahn et al. (2007) reported similar data for beef patties treated with grape seed extract. In all treatments $\mathrm{pH}$ values significantly increased $(\mathrm{p}<0.05)$ over 15 days of storage. Similar increases of $\mathrm{pH}$ values during storage in cooked ground meat have been reported in previous studies (Mc Carthy et al., 2001). They have been attributed to degradation and denaturation of proteins and amino acids leading to the exposure of basic groups (Choe et al., 2011). The samples with walnut leaf powder reached higher $\mathrm{pH}$ values $(\mathrm{p}<0.05)$ than the control samples after 15 days of storage while no significant differences were found among the other samples. This could be due to the higher microbial load of the walnut leaf powder relative to the thermal treated extracts.

Table 4. TBARS values, $\mathrm{pH}$, total phenolic content and ABTS antioxidant activity of the pork patties during refrigerated storage for 15 days

\begin{tabular}{|c|c|c|c|c|}
\hline \multirow{2}{*}{ Treatment $^{*}$} & \multicolumn{4}{|c|}{ Storage period (days) ${ }^{* *}$} \\
\hline & 0 & 5 & 10 & 15 \\
\hline \multicolumn{5}{|c|}{ TBARS values (mg MDA $/ \mathrm{kg}$ ) } \\
\hline $\mathrm{C} 0$ & $2.56 \pm 0.18^{\mathrm{dA}}$ & $2.74 \pm 0.13^{\mathrm{dAB}}$ & $2.84 \pm 0.15^{\mathrm{eAB}}$ & $3.01 \pm 0.26^{\mathrm{dB}}$ \\
\hline $\mathrm{C} 1$ & $1.80 \pm 0.11^{\mathrm{cA}}$ & $2.08 \pm 0.14^{c^{\mathrm{B}}}$ & $2.36 \pm 0.09^{\mathrm{dC}}$ & $2.43 \pm 0.18^{\mathrm{cC}}$ \\
\hline WLE & $0.98 \pm 0.08^{\mathrm{aA}}$ & $1.49 \pm 0.09^{\mathrm{bB}}$ & $1.50 \pm 0.10^{\mathrm{bB}}$ & $1.58 \pm 0.12^{\mathrm{bB}}$ \\
\hline CSE & $1.33 \pm 0.12^{\mathrm{bA}}$ & $1.52 \pm 0.06^{\mathrm{bA}}$ & $1.78 \pm 0.14^{\mathrm{CB}}$ & $1.83 \pm 0.15^{\mathrm{bB}}$ \\
\hline WLP & $0.88 \pm 0.06^{\mathrm{A}}$ & $0.93 \pm 0.05^{\mathrm{aA}}$ & $1.07 \pm 0.08^{\mathrm{aB}}$ & $1.19 \pm 0.08^{\mathrm{aB}}$ \\
\hline \multicolumn{5}{|c|}{$\mathrm{pH}$} \\
\hline $\mathrm{C} 0$ & $6.03 \pm 0.02^{\mathrm{bA}}$ & $6.02 \pm 0.02^{2 \mathrm{~A}}$ & $6.07 \pm 0.03^{\mathrm{aB}}$ & $6.16 \pm 0.02^{\mathrm{aC}}$ \\
\hline $\mathrm{C} 1$ & $5.95 \pm 0.03^{\mathrm{bA}}$ & $6.05 \pm 0.02^{\mathrm{ABB}}$ & $6.13 \pm 0.08^{\mathrm{abBC}}$ & $6.20 \pm 0.09^{\mathrm{abC}}$ \\
\hline WLE & $5.82 \pm 0.08^{\mathrm{aA}}$ & $6.02 \pm 0.05^{\mathrm{aB}}$ & $6.18 \pm 0.05^{\mathrm{bC}}$ & $6.22 \pm 0.07^{\mathrm{abC}}$ \\
\hline CSE & $5.97 \pm 0.08^{\mathrm{bA}}$ & $6.02 \pm 0.03^{\mathrm{aA}}$ & $6.21 \pm 0.05^{\mathrm{bB}}$ & $6.24 \pm 0.06^{\mathrm{abB}}$ \\
\hline WLP & $5.79 \pm 0.09^{\mathrm{aA}}$ & $6.04 \pm 0.04^{\mathrm{B}}$ & $6.20 \pm 0.08^{\mathrm{bC}}$ & $6.29 \pm 0.07^{\mathrm{bC}}$ \\
\hline \multicolumn{5}{|c|}{ Total phenolic content (mg GAE/100 g) } \\
\hline $\mathrm{C} 0$ & $7.17 \pm 0.32^{2 \mathrm{C}}$ & $7.02 \pm 0.40^{\mathrm{aBC}}$ & $6.47 \pm 0.33^{\mathrm{bB}}$ & $4.18 \pm 0.18^{\mathrm{aA}}$ \\
\hline $\mathrm{C} 1$ & $6.90 \pm 0.21^{\mathrm{aC}}$ & $6.70 \pm 0.35^{\mathrm{aC}}$ & $5.20 \pm 0.29^{\mathrm{aB}}$ & $3.95 \pm 0.25^{\mathrm{aA}}$ \\
\hline WLE & $9.72 \pm 0.38^{\mathrm{bC}}$ & $9.42 \pm 0.26^{\mathrm{BC}}$ & $8.85 \pm 0.36^{\mathrm{cB}}$ & $7.48 \pm 0.44^{\mathrm{AA}}$ \\
\hline CSE & $9.98 \pm 0.56^{\mathrm{bC}}$ & $8.08 \pm 0.66^{\mathrm{bB}}$ & $6.22 \pm 0.69^{\mathrm{bA}}$ & $5.62 \pm 0.5^{\mathrm{bA}}$ \\
\hline WLP & $15.62 \pm 0.49^{\circ \mathrm{C}}$ & $14.87 \pm 0.82^{\mathrm{dBC}}$ & $14.15 \pm 0.56^{\mathrm{dB}}$ & $10.53 \pm 0.61^{\mathrm{dA}}$ \\
\hline \multicolumn{5}{|c|}{ ABTS antioxidant activity (mmol Trolox/100 g) } \\
\hline $\mathrm{C} 0$ & $0.55 \pm 0.03^{\mathrm{aB}}$ & $0.52 \pm 0.02^{\mathrm{a}}$ & $0.47 \pm 0.02^{\mathrm{aA}}$ & $0.45 \pm 0.02^{2 \mathrm{~A}}$ \\
\hline $\mathrm{C} 1$ & $0.61 \pm 0.03^{\mathrm{bC}}$ & $0.56 \pm 0.03^{\mathrm{aB}}$ & $0.49 \pm 0.02^{\mathrm{aA}}$ & $0.47 \pm 0.02^{\mathrm{aA}}$ \\
\hline WLE & $0.66 \pm 0.02^{\mathrm{bB}}$ & $0.63 \pm 0.03^{\mathrm{bAB}}$ & $0.63 \pm 0.02^{\mathrm{bAB}}$ & $0.60 \pm 0.02^{\mathrm{bA}}$ \\
\hline CSE & $0.77 \pm 0.03^{\mathrm{cB}}$ & $0.76 \pm 0.02^{\mathrm{AB}}$ & $0.73 \pm 0.03^{\mathrm{cAB}}$ & $0.71 \pm 0.03^{\mathrm{cA}}$ \\
\hline WLP & $0.85 \pm 0.03^{\mathrm{dB}}$ & $0.84 \pm 0.03^{\mathrm{dB}}$ & $0.74 \pm 0.03^{\mathrm{cA}}$ & $0.73 \pm 0.03^{\mathrm{cA}}$ \\
\hline
\end{tabular}

${ }^{\overline{ }}$ Legend: $\mathrm{C} 0$ - Control (meat $+1.5 \%$ salt $+5.5 \%$ water); $\mathrm{C} 1$ - Control with BHT (meat $+1.5 \% \mathrm{w} / \mathrm{w}$ salt $+5.5 \%$ water $+0.1 \%$ BHT); WLE (meat $+1.5 \% \mathrm{w} / \mathrm{w}$ salt + $5.5 \%$ walnut leaf extract); CSE (meat $+1.5 \% \mathrm{w} / \mathrm{w}$ salt $+5.5 \%$ cherry stem extract); WLP (meat $+1.5 \% \mathrm{w} / \mathrm{w}$ salt $+5.5 \%$ water $+0.5 \%$ walnut leaf powder) ${ }^{* *}$ Different lowercase letters indicate significant difference at $\mathrm{p}<0.05$ level between different treatments, while different uppercase letters are indicative of the same within each treatment during the storage period. 
768

\section{Total phenolic content}

The average phenolic content was significantly $(\mathrm{p}<0.05)$ higher in WLE, CSE and WLP treatments than CO (7.17 $\mathrm{mg} / 100 \mathrm{~g})$ and $\mathrm{C} 1(6.90 \mathrm{mg} / 100 \mathrm{~g})$. Among treatments, WLP significantly $(p<0.05)$ increased the phenolics content (15.62 mg GAE/100 g) of pork patties followed by CSE (9.98 mg GAE/100 g) and WLE (9.72 mg GAE/100 g). The evolution of phenolic content indicated a continuous and significant $(\mathrm{p}<0.05)$ decrease in phenolics up to 15th day of storage. Percentage decrease of total phenolics during storage was significantly $(\mathrm{p}<0.05)$ higher in C1 $(42.7 \%)$ followed by C0 (41.7\%), CSE (40.6\%), WLP (32.6\%), and WLE (23.0\%) (Table 4). These results indicated that treatments with walnut leaf powder and extracts showed significantly $(p<0.05)$ higher phenolics during storage period.

\section{ABTS free radical scavenging activity}

According to the ABTS assay, the treatments with walnut leaf and cherry stem powder and extracts significantly $(\mathrm{p}<0.05)$ increased antioxidant activity in cooked pork patties as compared to control and even BHT treated samples (Table 4), in good agreement with previous studies reporting on the addition of antioxidant plant extracts or powders to meat and meat products (Huang $e t$ al., 2011). Radical scavenging activity decreased during storage in all meat samples. After 15 days of storage, antioxidant activity was significantly higher in samples with phenolic-rich extracts and powder than in controls while no significant difference was found between control without antioxidant and BHT treated samples.

\section{Lipid oxidation}

Table 4 illustrates the effect of the treatment and storage on the TBARS values in cooked pork patties stored for 15 days. The results show that lipid oxidation was retarded in the antioxidant treated samples. The initial lipid oxidation level (at day 0) ranged from 0.88 to $2.56 \mathrm{mg} \mathrm{MDA} / \mathrm{kg}$ in meat samples. The TBARS values of the cooked pork patties made with WLP and WLE were significantly lower than those of the other samples on the initial storage day. A stronger antioxidative effect was also observed with the walnut leaf than with the cherry stem since a lower TBARS value was reached in the pork patties ( 0.98 vs 1.33 , for WLE and CSE, respectively, $\mathrm{p}<0.05)$. The same trend was observed at day 10 of storage with significant differences between treatments $(\mathrm{p}<0.05)$.

The storage also affected the MDA concentration, and TBARS values gradually increased with increasing storage time in all samples, ranging from 1.09 to $3.21 \mathrm{mg} \mathrm{MDA} / \mathrm{kg}$ after 15 days at $4{ }^{\circ} \mathrm{C}$. However, during all storage intervals TBARS values were higher $(\mathrm{p}<0.05)$ in the control without antioxidant than in those containing walnut leaf and cherry stem extracts.

Over the 15-day storage period, TBARS values were reduced by $47.5 \%$ and $39.2 \%$ in cooked pork patties with WLE and CSE, respectively, as compared with the control; therefore, the addition of these extracts had significant lipid oxidation reduction effects in the cooked ground pork samples.

Table 5. Sensory evaluation of pork patties during refrigerated storage for 15 days

\begin{tabular}{|c|c|c|c|c|c|}
\hline & \multirow{2}{*}{ Treatment* } & \multicolumn{4}{|c|}{ Storage period (days) ${ }^{* *}$} \\
\hline & & 0 & 5 & 10 & 15 \\
\hline \multirow{5}{*}{ Appearance } & $\mathrm{C} 0$ & $7.25 \pm 0.62^{a}$ & $7.08 \pm 0.51^{a}$ & $6.75 \pm 0.45^{a}$ & $6.25 \pm 0.45^{a}$ \\
\hline & $\mathrm{C} 1$ & $7.42 \pm 0.51^{a}$ & $7.33 \pm 0.49^{\mathrm{ab}}$ & $7.08 \pm 0.51^{\mathrm{ab}}$ & $6.75 \pm 0.62^{\mathrm{b}}$ \\
\hline & WLE & $7.67 \pm 0.49^{a}$ & $7.58 \pm 0.51^{\mathrm{b}}$ & $7.50 \pm 0.52^{c}$ & $7.08 \pm 0.29^{b}$ \\
\hline & CSE & $7.50 \pm 0.52^{\mathrm{a}}$ & $7.42 \pm 0.51^{\mathrm{ab}}$ & $7.33 \pm 0.49^{b c}$ & $6.92 \pm 0.29^{\mathrm{b}}$ \\
\hline & WLP & $8.33 \pm 0.49^{b}$ & $8.33 \pm 0.49^{c}$ & $8.17 \pm 0.39^{d}$ & $7.83 \pm 0.39^{c}$ \\
\hline \multirow{5}{*}{ Color } & $\mathrm{C} 0$ & $6.67 \pm 0.75^{\mathrm{a}}$ & $6.58 \pm 0.51^{a}$ & $6.42 \pm 0.51^{a}$ & $6.25 \pm 0.45^{\mathrm{a}}$ \\
\hline & $\mathrm{C} 1$ & $7.08 \pm 0.79^{\mathrm{ab}}$ & $7.08 \pm 0.79^{\mathrm{ab}}$ & $6.92 \pm 0.67^{b}$ & $6.75 \pm 0.45^{\mathrm{b}}$ \\
\hline & WLE & $7.33 \pm 0.98^{\mathrm{bc}}$ & $7.25 \pm 0.87^{b c}$ & $7.17 \pm 0.83^{b}$ & $7.00 \pm 0.74^{b}$ \\
\hline & CSE & $7.25 \pm 0.45^{\mathrm{b}}$ & $7.08 \pm 0.51^{\mathrm{ab}}$ & $6.83 \pm 0.39^{\mathrm{ab}}$ & $6.92 \pm 0.29^{\mathrm{b}}$ \\
\hline & WLP & $7.83 \pm 0.39^{c}$ & $7.75 \pm 0.45^{c}$ & $7.67 \pm 0.49^{c}$ & $7.75 \pm 0.45^{c}$ \\
\hline \multirow{5}{*}{ Flavor } & $\mathrm{C} 0$ & $7.67 \pm 0.65^{a}$ & $7.33 \pm 0.49^{a}$ & $7.17 \pm 0.58^{a}$ & $6.42 \pm 0.51^{a}$ \\
\hline & $\mathrm{C} 1$ & $7.75 \pm 0.62^{\mathrm{a}}$ & $7.42 \pm 0.51^{a}$ & $7.33 \pm 0.49^{\mathrm{ab}}$ & $6.67 \pm 0.49^{\mathrm{ab}}$ \\
\hline & WLE & $7.67 \pm 0.65^{a}$ & $7.58 \pm 0.67^{\mathrm{a}}$ & $7.42 \pm 0.51^{\mathrm{ab}}$ & $7.08 \pm 0.79^{\mathrm{b}}$ \\
\hline & CSE & $7.58 \pm 0.51^{a}$ & $7.42 \pm 0.51^{\mathrm{a}}$ & $7.25 \pm 0.62^{\mathrm{a}}$ & $7.00 \pm 0.60^{\mathrm{b}}$ \\
\hline & WLP & $8.33 \pm 0.49^{b}$ & $8.17 \pm 0.39^{b}$ & $7.75 \pm 0.45^{b}$ & $7.58 \pm 0.51^{\mathrm{c}}$ \\
\hline \multirow{5}{*}{ General acceptability } & $\mathrm{C} 0$ & $7.42 \pm 0.51^{a}$ & $7.08 \pm 0.29^{a}$ & $6.92 \pm 0.67^{a}$ & $6.00 \pm 0.60^{a}$ \\
\hline & $\mathrm{C} 1$ & $7.50 \pm 0.52^{\mathrm{a}}$ & $7.17 \pm 0.58^{\mathrm{a}}$ & $7.08 \pm 0.51^{\mathrm{ab}}$ & $6.25 \pm 0.75^{\mathrm{ab}}$ \\
\hline & WLE & $7.42 \pm 0.51^{a}$ & $7.33 \pm 0.49^{a}$ & $7.17 \pm 0.58^{\mathrm{ab}}$ & $6.67 \pm 0.65^{b}$ \\
\hline & CSE & $7.33 \pm 0.49^{a}$ & $7.17 \pm 0.39^{a}$ & $7.00 \pm 0.43^{\mathrm{a}}$ & $6.58 \pm 0.5 \mathrm{l}^{\mathrm{b}}$ \\
\hline & WLP & $8.08 \pm 0.29^{b}$ & $7.92 \pm 0.51^{b}$ & $7.50 \pm 0.52^{\mathrm{b}}$ & $7.25 \pm 0.45^{c}$ \\
\hline
\end{tabular}

$5.5 \%$ walnut leaf extract); CSE (meat $+1.5 \% \mathrm{w} / \mathrm{w}$ salt $+5.5 \%$ cherry stem extract); WLP (meat $+1.5 \% \mathrm{w} / \mathrm{w}$ salt $+5.5 \%$ water $+0.5 \%$ walnut leaf powder)

${ }^{* *}$ Means with different superscript within a column are significantly different $(p<0.05)$ 
WLE was more effective against lipid oxidation than CSE, which is in agreement with results from the in vitro assays. The walnut leaf extract showed a higher flavonoids content than the cherry stem extract, which is directly related with the higher antioxidant capacity (3.67 vs 2.84 $\mathrm{mmol} / 100 \mathrm{~g}$ Trolox for walnut leaf and cherry stem extract, respectively) (Table 1) and, consequently, with the more intense antioxidative effect of the first extract.

Lipid oxidation was minimal in WLP-treated samples as the increase in TBARS number was very slow and remained lowest $(1.19 \mathrm{mg} \mathrm{MDA} / \mathrm{kg}$ ) by the end of the storage (day 15). Walnut leaf and cherry stem extracts were found to be more effective in preventing lipid oxidation in cooked pork patties than BHT, demonstrating their efficiency as antioxidants in cooked pork meat. These oxidation retarding effects of walnut leaves and cherry stems may be due to their high content of phenolic compounds which act as antioxidants (Lapornik et al., 2005).

Similar results were found with other antioxidant plant extracts and powder such as green tea extracts in raw and cooked ground pork (Jo et al., 2003) and beef patties (Bañón et al., 2007), Moringa oleiferia leaves extract in cooked goat meat patties (Das et al., 2012), pomegranate juice and pomegranate rind powder in cooked chicken patties (Naveena et al., 2008), lotus leaf and barley leaf powder in cooked ground pork (Choe et al., 2011), lotus rhizome knot and leaf extracts in ground cooked bovine and porcine meat (Huang et al., 2011).

\section{Sensory evaluation}

The sensory evaluation data for cooked pork patties are presented in Table 5 . After cooking (day 0), there were no significant differences in the overall appearance, flavor and general acceptability of control and treated samples, except patties treated with WLP whose scores were significantly higher. Similarly, supplementation of natural antioxidant such as lotus leaf and barley leaf powder had no significant effect on the overall acceptability of cooked ground pork (Choe et al., 2011) while addition of Moringa oleiferia leaves extract had no effect on the sensory attributes of cooked goat meat patties (Das et al., 2012).

Increasing storage time resulted in reduced sensory attributes in all treatments. After 15 days of refrigerated storage, pork patties containing walnut leaf and cherry stem extracts were sensorially acceptable, and addition of extracts had positive effects on sensory attributes. Therefore, these extracts have the potential to reduce oxidative rancidity and improve acceptability and shelf life of cooked pork patties. At the end of the storage period, the scores for WLP-treated samples were significantly higher than those of the controls and of the other treatments. No significant differences were found between scores of samples treated with phenolic-rich extracts and BHT treated samples while the scores for control samples without antioxidant were significantly lower, particularly in regards to color.

\section{Conclusions}

From the results, it could be concluded that walnut leaf powder and extracts from walnut leaves and cherry stems exhibited high phenolic content and potent antioxidant activity. Addition of these phenolic-rich products to cooked pork patties were found to be more effective than $0.1 \%$ BHT in retarding lipid oxidation and color deterioration during refrigerated storage. The lowest lipid oxidation values were found in pork patties containing walnut leaf powder that showed a potent antioxidant effect. Walnut leaf extract was more effective against lipid oxidation than cherry stem extract which is in agreement with results from the in vitro assays. Consistently, walnut leaf extract had a more intense antioxidant activity, probably as a result of the higher content of flavonoids as against the cherry stem extract. The addition of walnut leaf and cherry stem extracts did not affect the appearance, flavor and general acceptability of cooked pork patties at $5.5 \%$ level of addition tested in the current research while addition of walnut leaf powder at $0.5 \%$ had significant positive effects on the sensory attributes. The results suggest that walnut leaves and cherry stems have potential to be used as natural antioxidants in meat products.

\section{References}

Ademović Z, Hodžić S, Zahirović ZH, Husejnagić D, Džananović J, ŠarićKundalić B, Suljagić J (2017). Phenolic compounds, antioxidant and antimicrobial properties of the wild cherry (Prumus avium L.) stem. Acta Periodica Tehnologica 48:1-13.

Ahn J, Grun IU,Mustaphab A (2007). Effects of plant extracts on microbial growth, color change, and lipid oxidation in cooked beef. Food Microbiology 24(1):7-14.

Amaral JS, Seabra RM, Andrade PB (2004). Phenolic profile in the quality control of walnut (Juglans regia L.) leaves. Food Chemistry 88(3):373379.

Balasundram N, Sundram K, Samman S (2006). Phenolic compounds in plants and agri-industrial by products: Antioxidant activity, occurrence and potential uses. Food Chemistry 99(1):191-203.

Banerjee R, Verma AK, Das AK, Rajkumar V, Shewalkar AA, Narkhede $\mathrm{HP}$ (2012). Antioxidant effects of broccoli powder extract in goat meat nuggets. Meat Science 91(2):179-184.

Bañón S, Díaz P, Rodríguez M, María DG, Alejandra P (2007). Ascorbate, green tea and grape seed extracts increase the shefflife of low sulphite beet patties. Meat Science 77(4):626-633.

Bastos C, Barros L, Dueñas M, Calhelha RC, Queiroz MJRP, Santos-Buelga C, Ferreira ICFR (2015). Chemical characterisation and bioactive properties of Prunus avium L.: The widely studied fruits and the unexplored stems. Food Chemistry 173:1045-1053.

Biswas AK, Chatli MK, Sahoo J (2012). Antioxidant potential of curry (Murrayakoenigii L.) and mint (Mentha spicata) leaf extracts and their effect on colour and oxidative stability of raw ground pork meat during refrigeration storage. Food Chemistry 133(2):467-472.

Carpenter R, O'Grady MN, O'Callaghan YC, O'Brien NM, Kerry JP (2007). Evaluation of the antioxidant potential of grape seed and bearberry extracts in raw and cooked pork Meat Science 76(4):604610.

Carvalho M, Ferreira PJ, Mendes VS, Silva R, Pereira JA, Jeronimo C, Silva BM (2010). Human cancer cell antiproliferative and antioxidant activities of Juglans regia $\mathrm{L}$. Food and Chemical Toxicology 48(1):441447. 
770

Chell I, Gatellier P, Santé-Lhoutellier V (2007). Characterization of fluorescent Schiff bases formed during oxidation of pig myofibrils. Meat Science 76(2):210-215.

Choe JH, Jang A, Lee ES, Choi JH, Choi YS, Han DJ, ... Kim CJ (2011). Oxidative and color stability of cooked ground pork containinglotus leat (Nelumbo nuifera) and barley leaf (Hordeum vulgare) powder during refrigerated storage. Meat Science 87(1):12-18.

Contini C, Alvarez R, O'Sullivana M, Dowling DP, Gargan SO, Monahan FJ (2014). Effect of an active packaging with citrus extract on lipid oxidation and sensory quality of cooked turkey meat. Meat Science 96(3):1171-1176.

Das AK, RajkumarV,Verma AK,SwarupD (2012).Moringa oleiferialeaves extract: a natural antioxidant for retarding lipid peroxidation in cooked goat meat patties. International Journal of Food Science \& Technology 47(3):585-591.

Devatkal SK, Narsaiah K, Borah A (2011). The effect of salt, extract of kinnow and pomegranate fruit by-products on colour and oxidative stability of raw chicken patties during refrigerated storage. Journal of Food Science and Technology-Mysore 48(4):472477.

Falowo AB, Fayemi PO, Muchenje V (2014). Natural antioxidants against lipid-protein oxidative deterioration in meat and meat products: A review. Food Research Intemational 64:171-181.

Hayes JE, Stepanyan V, Allen P, O’Grady MN, KerryJP (2011). Evaluation of the effects of selected plant-derived nutraceuticals on the quality and shelflife stability of raw and cooked pork sausages. LWT - Food Science and Technology 44(1):164172.

Hooman N, Mojab F, Nickavar B, Pouryousefi-Kermani P (2009). Diuretic effect of powdered Cerasus avium (cherry) tails on healthy volunteers. Pakistan Journal of Pharmaceutical Sciences 22(4):381-383.

Huang B, He J, Ban X, Zeng H, Yao X, Wang Y (2011). Antioxidant activity of bovine and porcine meat treated with extracts from edible lotus (Nelumbo nucifera) thizome knot and leaf. Meat Science 87(1):4653.

Jia N, Kong B, Liu Q, Diao X, Xia X (2012). Antioxidant activity of black currant (Ribes nigrum L.) extract and its inhibitory effect on lipid and protein oxidation of pork patties during chilled storage. Meat Science 91(4):533-539.

Jo C, Son JH, Son CB, Byun MW (2003). Functional properties of raw and cooked pork patties with added irradiated, freeze-dried green tea leat extract powder during storage at $4^{\circ} \mathrm{C}$. Meat Science 64(1):13-17.

Kanatt SR, Chander R, Sharma A (2010). Antioxidant and antimicrobial activity of pomegranate peel extract improves the shelf life of chicken products. International Journal of Food Science \& Technology 45(2):216-222.

Karre L, Lopez K, Getty KJK (2013). Natural antioxidants in meat and poultry products. Meat Science 94(2):220-227.

Kaumar S, Harkonen PL, Arora S, Kaur M (2003). Studies on correlation of antimutagenic and antiproliferative activities of Juglans regia $\mathrm{L}$. Journal of Environmental Pathology, Toxicology and Oncology 22(1):59-67.

Kim S, Cho AR, Han J (2013). Antioxidant and antimicrobial activities of leafy green vegetable extracts and their applications to meat product preservation. Food Control 29(1):112-120.
Kobus-Cisowska J, Flaczyk E, Rudzińska M, Kmiecik D (2014). Antioxidant properties of extracts from Ginkgo biloba leaves in meatballs. Meat Science 97(2):174-180.

Lapornik B, Prosek M, Wondra AG (2005). Comparison of extracts prepared from plant by-products using different solvents and extraction time.Journal of Food Engineering 71(2):214222.

Lynch MP, Faustman C (2000). Effect of aldehyde lipid oxidation products on myoglobin. Journal of Agricultural and Food Chemistry 48(3):600604.

Martinez ML, Labuckas DO, Lamarque AL, Maestri DM (2010). Walnut (Juglans regia L.): genetic resources, chemistry, by-products. Journal of the Science of Food and Agriculture 90(12):1959-1967.

Mc Carthy TL, Kerry JP, Kerry JF, Lynch PB, Buckley DJ (2001). Assessment of the antioxidant potential of natural food and plant extracts in fresh and previously frozen pork patties. Meat Science 57(2):177-184.

Moylan S, Michael B, Dean OM, Samuni Y, Williams L, O’Neil A, ... Maes $\mathrm{M}$ (2014). Oxidative and nitrosative stress in depression: Why so much stress? Neuroscience \& Biobehavioral Reviews 45:46-62.

Naveena BM, Sen AR, Vaithiyanathan S, Babji Y, Kondaiah N (2008). Comparative efficacy of pomegranate juice, pomegranate rind powder extract and BHT as antioxidants in cooked chicken patties. Meat Science 80(4):1304-1308.

Nerín C, Tovar L, Djenane D, Camo J, Salafranca J, Beltrán, JA, Roncalés P (2006). Studies on the stabilization of beef meat by new active packaging containing natural antioxidants. Journal of Agricultural and Food Chemistry 54(20):7840-7846.

Palmieri B, Sblendorio V (2007). Oxidative stress tests: Overview on reliability and use. Part II. European Review for Medical and Pharmacological Sciences 11(6):383-399.

Pereira JA, Oliveira I, Sousa A, Valentaŏ P, Andrade PB, Ferreira ICFR,... Estevinho L (2007). Walnut (Juglans regia L.) leaves: Phenolic compounds, antibacterial activity and antioxidant potential of different cultivars. Food and Chemical Toxicology 45(11):2287-2295.

Qin Y-Y, Zhang Z-H, Li L, Xiong W, Shi J-Y, Zhao T-R, Fan J (2013). Antioxidant effect of pomegranate rind powder extract, pomegranate juice, and pomegranate seed powder extract as antioxidants in raw ground pork meat. Food Science and Biotechnology 22(4):1063-1069.

Rababah T, Hettiarachchy NS, Horax R, Cho MJ, Davis B, Dickson J (2006). Thiobarbituric acid reactive substances and volatile compounds in chicken breast meat infused with plant extracts and subjected to electron beam irradiation. Poultry Science 85(6):1107-1113.

ReR, Pellegrini N, Proteggente A, Pannala A, YangM, Rice-Evans C (1999). Antioxidant activity applying an improved ABTS radical cation decolorization assay. Free Radical Biology \& Medicine 26(9-10):12311237.

Rodriguez-Carpena JG, Morcuende D, Estévez M (2011). Avocado byproducts as inhibitors of color deterioration and lipid and protein oxidation in raw porcine patties subjected to chilled storage. Meat Science 89(2):166-173.

Rojas MC, Brewer S (2008). Effect of natural antioxidants on oxidative stability of frozen, vacuum-packaged beef and pork. Journal of Food Quality31(2):173-188. 
Salimi M, Majd A, Sepahdar Z, Azadmanesh K, Irian S, Ardestaniyan MH, ... Rastkari N (2012). Cytotoxicity effects of various Juglans regia (walnut) leaf extracts in human cancer cell lines. Pharmaceutical Biology 50(11):1416-1422.

Sampaio GR, Saldanha T, Soares RAM, Torres EAFS (2012). Effect of natural antioxidant combinations on lipid oxidation in cooked chicken meat during refrigerated storage. Food Chemistry 135(3):1383-1390.

Sanchez-Muniz FJ, Olivero-David R, Triki M, Salcedo L, Gonzalez-Munoz MJ, Cofrades S, ... Benedi J (2012). Antioxidant activity of Hypericum perforatum $\mathrm{L}$. extract in enriched $\mathrm{n}-3$ PUFA pork meat systems during chilled storage. Food Research International 48(2):909-915.

Selani MM, Contreras-Castillo CJ, Shirahigue LD, Gallo CR, Plata-Oviedo M, Montes-Villanueva ND (2011). Wine industry residues extracts as natural antioxidants in raw and cooked chicken meat during frozen storage. MeatScience 88(3):397-403.
Singleton VL, Orthofer R, Lamuela-Raventos RM (1999). Analysis of total phenols and other oxidation substrates and antioxidants by means of Folin-Ciocalteu reagent. In: Packer L (Ed). Methods in Enzymolology Academic Press: Orlando, FL, 1999; Vol 299,pp 152-178.

Smet K, Raes K, Huyghebaert G, Haak L, Arnouts S, De Smet S (2008). Lipid and protein oxidation of broiler meat as influenced by dietary natural antioxidant supplementation. Poultry Science 87(8):1682-1688

Xiao S, Zhang WG, Lee EJ, Ahn DU (2013). Effects of diet, packaging and irradiation on protein oxidation, lipid oxidation of raw broiler thigh meat. Animal Industry Report, AS 659, ASL R2761.

Witte VC, Krauze GF, Bailey ME (1970). A new extraction method for determining 2-thiobarbituric acid values of pork and beef during storage Journal of Food Science 35(5):582-585.

Zhishen J, Mengcheng T, Jianming W (1999). The determination of flavonoid contents in mulberry and their scavenging effects on superoxide radicals. Food Chemistry 64(4):555-559. 